https://doi.org/10.46344/JBINO.2020.v09i03.08

\title{
IMPORTANCE OF NIDRA[SLEEP]- IN AYURVEDIC AND MODERN ERA -A REVEIW
}

\author{
Hiremath Parameshwar ${ }^{1}$ \& Dr. Shashi Bhushan Sahu
}

'ASSOCIATE PROFESSOR, DEPARTMENT OF SHAREERA KRIYA, SJG AYURVEDIC MEDICAL COLLEGE AND HOSPITAL, KopPal-583231, Karnataka, India.

Final Year PG Scholar, Dept. of Kriya Shareer, SJGAMC, Koppal

\begin{abstract}
Nidra gives nourishment to the body, keeping us away from the diseases. Nidra is one which helps to attain longevity, memory, intelligence, and freedom from illness. And maintenance of youthfulness, excellence of luster, complexion, voice, optimum development of physique and sense organs, mastery over phonetics, and brilliance. It is also helpful to increase the immunity of the person to keep him away from the disease, also reverses the disease processes and prevents the reoccurrence. So Nidra is one important upasthambha that is described in Ayurveda. Sleep is the periodic state of rest of mind with closed eyes characterised by partial or complete loss of consciousness. Loss of consciousness leads to decreased response to external stimuli and decreased body movements. Depth of sleep is not constant thought the sleeping period. Sleep is needed for well life and it is proved by researches. Here an attempt is made to describe the importance of Nidra (Sleep) and to enumerate its utility as upasthambha.
\end{abstract}

Keywords: Ayurveda, Trayopasthambha, Swapna, Medhaswi 


\section{INTRODUCTION}

Ayurveda is the most ancient science of life, which is having an aim of curing and preventing a disease. It makes the holistic approach to the life and its well being. Ayu the life is considered as fourdimensional entity comprising of the physical body, the senses, the psyche and the soul(consciousness). Ayu the individual life entity is considered as miniature replica of the universe. The Nidra is so important for maintenance of health. This is true in the light of modern scientific knowledge also. According to Ayurvedic concept, the Kapha and Tamas are responsible for Nidra. Sleep production has been attributed to many factors which include stimulation of certain areas of brain, food activities, external stimuli etc. Any variation in the normal sleep pattern is not at all desirable thing and they may cause the serious health problem which demand more proper medical attention.

For maintaining healthy life 3 Upasthambas are needed'. Charaka and Vagbhata explains Trayopasthamba, Such Trayopasthmaba are Ahara, Nidra and Brahmacharya.

The term 'Nidra' origine as "nindyate iti nidra" (Sabdakalpadrumam). The word 'nidra' is derived from nind+ ruk+tap= na lopa'. Means that "Nothing loss is there". In Upanishads also explanation about Nidra is there. So that while explanation about diff. types of Avastha, like Jagrutavastha, Swapnavastha, Sushiptavastha, and Trutiyavastha ${ }^{3}$. Nidra is one among the Adharaniya Vega which was explained in Charaka. ${ }^{4}$

Sleep is a such factor which occupies probably one third of human life span 5 . It is a process the brain requires for proper functioning. Sleep can be associated with the high degree of brain activation. Sleep is regulated by several basic mechanisms and when these systems go wrong sleep disorders occur. 6

\section{PARYAYAS:}

The Paryayas of Nidra 7 are as followsShayaanam, Swapa, Sushipti, Nidra, Swapna.

\section{NIDRA UTPATTI:}

Nidra is an essential phenomenon to provide rest and relaxation to the body, mind and senses which gets tired and exhausted 8 . Sleep also balances mind and emotions. Nidra is a state where predominance of Kapha and Tamas is seen?. Utpatti (origin) of Nidra was explained by giving importance to Hridaya which is considred as Chetana stana. When Chetana stana Hridaya is enveloped by Tamas, the person goes to sleep ${ }^{10}$. Also stated that at night Tamas being powerful and higher psychic centres being over powered by it, then sleep occurs ${ }^{11}$.

HETUS OF NIDRA:

The Nidrajanaka hetus are- Abyanga, Utsadana, Snana, Ksheera, Sneha, Madya and Manasukha. ${ }^{12}$ 
NIDRA LAXANAS:

The Nidra is important psycophysiological states of human being. Yoga sutra describes five altered states of internal TYPES OF NIDRA: organs, like Pramana, Viparyaya, Vikalpa, Smruti and Nidra ${ }^{12}$. Among these states the Nidra is that condition which takes place on the quitting all the objects ${ }^{13}$.

The types of Nidra are diff. according to diff. Acharyas ${ }^{14-16}$.

\begin{tabular}{|l|l|l|l|l|}
\hline $\begin{array}{l}\text { SL. } \\
\text { No }\end{array}$ & Charaka & Sushruta & V.vagbhata & Vagbhata \\
\hline 1) & Tamobhava & Tamasi & Kalaswabhavajanya & Mithyayoga \\
\hline 2) & ShleshmoSamudbhava & $\begin{array}{l}\text { Swabhavaki- } \\
\text { a)Tamobuyishta } \\
\text { b)Rajobuyishta } \\
\text { c)Satwabhuyist }\end{array}$ & Amayaja & Hinayoga \\
\hline 3) & Manashramasambhava & Vaikariki & Chittakedodbhva & Atiyoga \\
\hline 4) & Shareeashrama sambhava & & Dehakedodbhava & Samyakyoga \\
\hline 5) & Aaguntaki & & Shleshmaprabhava & \\
\hline 6$)$ & Vyadinuvartini & & Agantubhava & \\
\hline 7$)$ & Ratriswabhava Prabhavaa & & Tamobhava & \\
\hline
\end{tabular}

A human being is needed minimum hours in different avasthas(age) as Shows general recommendations of sleep for different age groups ${ }^{[17]}$.

\begin{tabular}{|l|l|}
\hline Age & Recommended amount of sleep \\
\hline Newborn & $16-18 \mathrm{hrs}$ a day \\
\hline Pre-school aged children & $11-12 \mathrm{hrs}$ a day \\
\hline School aged children & At least $10 \mathrm{hrs}$ a day \\
\hline Teens & $9-10 \mathrm{hrs}$ a day \\
\hline Adults (including the elderly) & $7-8 \mathrm{hrs}$ a day \\
\hline
\end{tabular}

\section{FUNCTIONS OF NIDRA:}

Happy status of mind, nourishment of the body, strength of body, virility, knowledge, and life are gifts of sleep. Sleep is one of the factors responsible for sustaining living body. It participates in happiness, misery, nourishment, emaciation, strength, weakness, sexual urge, impotency, learning and illiteracy, life and death.

Nidra is one among the adharneeya Vega, if we have done dharana it causes the Jrumba, Angamarda, Tandra, Shiroroga and Netraroga. ${ }^{18}$

\section{BENEFITS OF SLEEP}

2020 May Edition | www.jbino.com | Innovative Association 
Sleep is one of the four basic, natural instincts and is considered as the pioneer for health, the remaining three being the desire to eat, drink and have sexual contact. Properly and timely taken sleep brings the happiness, nourishment, strength, virility, knowledge and maintains the life. As the real knowledge brings about Siddhi in a Yogi similarly properly taken sleep brings about longevity in human beings. Sleep makes the balance of the body constituents, provides alertness, good vision, complexion, strength and digestive power. Sleep also necessary for the mental functions like peaceful mind, enthusiasm, learning, memory and happiness.

An experimental study published in BMJ says that, an illustrated by the expression 'beauty sleep' an individual's sleep history may play an integral part in the perception and judgement of his or her attrac- tiveness and health. Sleep deprived people are per- ceived as less attractive, less healthy, and more tired compared with when they are well rested Recent work points to sleep acting as an adjuvant to enhance the early stage of immune response. It has been ob- served that people sleeping for 7-9 hours /day have significantly lower rates of illness 1 .

DIWASWAPNA20:

If we have done sleep at day time, it causes snigdhata, if we awaken at night time it causes rukshta in the body. Diwaswapna if done in Greeshma rutu, its good for health. But in some persons who are indulged in madyapaan, vamana, suffering from ajirna, atisara, who are vriddha, balaka, such persons are able to have nidra in day time.

DIWASWAPNA NISHEDHA: Our Acharyas are rejected to have sleep at day time because its cause for kapha vriddhi and pitta prakoapa. So in other ritus one should not take sleep at day time. The persons who are medhaswi (increase Medho Dhatu), snehanitya, kapha prakriti purusha, kapha rogi, dushi visha rogi, in these persons its strictly prohibited to have day time sleep. If we have sleep in day time it causes harmful effects such as- Haleemaka(Chlorosis), Shirashula, Stimitya, Guru Gatrata, Angamarda, Agninasha, Kasa, Pinasa, Kandu, Ardhavabedaka, Kantharogas, Buddhibramsha, Smritinasha, Srotoavarodha, Jwara, Indriyas Asamarthya, Vishavega Prarambha all these are harmful effects of diwaswapna.

ATINIDRA: To avoid the atinidra one should undergo for the virechana, nasya, vamanam and make the person to experience bhaya, krodha, shoka, chinta, has to undergo dhumapana, vyayama, raktamokshana, upavasa. Not only these the other reasons are like to take sleep in asatmya kala, prakriti, and also it leads in vata vriddhi

ANIDRA: To avoid Anidra one should take every day the abhyanga, utsadana, snana, gramya, anupa mamsa rasa, dadhi, ksheera, sneha and madya. And one should have netratarpana ${ }^{21}$,

\section{DISCUSSION}


Now in modern text books scholars are more focusing over the water, food, sleep. But about this, before thousand years our Acharyas have told about Nidra and ahara under the heading of Trayopasthamba. As pillars support the house in the same way food, sleep, and sexual activities support the living body.

Now a day's one of the common problems for infertility is Nidra. The people now a day in their busy schedule are not having the proper time for food and sleep. Some people are having the duty at night time, and then they are not able to take sleep. Due to not getting sleep at day time, the persons are suffering from anxiety and other psychological problems which will leads to infertility. So, our Acharyas have given importance to sleep as one of the pillars for life.

And also, while explanation of the Paryayas the word shayana is mentioned it may be due to the sleep should be done in shayyarastha because only by sitting we cannot sleep properly, so this word may used. swap and swapna indicates about dreams where Nidra is required to experience swapna.

While explanations about the types of Nidra all are telling the same types and giving the same meaning. Only numbers are mentioned differently.

More than half of the life is invariably spent in sleep hence if it is not enjoyed properly it may lead to several disturbances and at the same time if it is properly enjoyed it proves most beneficial to the life.
Importance of sleep is highlighted by considering sleep as one of the Trayopasthambha. The timely taken sleep is an indicator of good health because it brings the normalcy in body tissues and relaxes the person, like food the adequate sleep is essential for maintenance of the body. While looking into the de- scription of Nidra, one can also classify sleep as Kalaja and Akalaja. When the mind including sensory and motor organs is exhausted and they dissociates themselves from their objects which is produced by the accustomed time (night) then it can be con- sidered as Kaalaja Nidra (Timely taken Sleep). Sleeping during day time lexcept in some condi- tions), due to effect of diseases, excess fatigue of body and mind, excessive increase in Kapha and Tama Guna leads to Akaalaja Nidra (untimely taken sleep).

Irregular and unnatural food habits, suppression of natural urges or inappropriate sleep habits due to work shifts, watching T.V or electronic gadgets till late night etc have become inseparable parts of daily routine. In Ayurveda these factors have mentioned under Aharaja and Viharaja Nidana. One feels sleepy when body, mind and senses are in rest or in relaxed state. But in present era stress and strains of day to day life increases tension, anxiety, fear etc. People themselves are inviting various physical as well as mental disorders, because of indulging in Manasika Nidana. In Nidranasha premonitory symptoms are Avyaktha (not clearly manifested) but when person develops problem in 
initiating and /or maintaining sleep then that can be considered as a premonitory symptom of Nidranasha and effort should be made to find the root cause for the distur- bance of sleep and advice is given to avoid the causative factor or treatment should be started at the earliest for the early recovery. While looking into the symptom like Jrumbha, Angamarda, Shirogaurava etc one can elicit the vitiation of Vata and Kapha Dosha. This is the reason all Vatahara and Kaphakara treatment measures are considered as Upashaya to Nidranasha. One which gives psychic pleasure like meditation, Pranayama, relaxation technique and smoothening music can be practiced in the present era.

\section{CONCLUSION}

Timely sleep offers appropriate weight gain, better complexion, desire to work, fresh and alert status of sensory organs. It is also responsible for balanced status of the body entities. Gaining or losing weight is directly dependent on their principle factors in physiology of living being namely ahara, nidra, brahmacharya. Thus, these are proved as Trayopasthambha.

Sleep if not taken in appropriate quantity will lead to several diseases. Thus, proper Nidra is essential to fulfill both the aims of Ayurveda that is prevention and cure of diseases.

Sleep plays a very essential role in physical and mental wellbeing. Abnormal sleep patterns lead to misery, improper growth, weakness, sterility, igno- rance, and finally death. So, while treating Nidra nasha physician should give importance to Nidana Panchanka for better management of Nidranasha.

\section{REFERENCES}

1. Trikamjin Yadavji. Charaka Samhita with Chakrapanidatta Ayurvedadipika commentary. Reprint ed. Varanasi (India): Chaukhamba Surbharati Prakashana ;2011. p.74.

2.

\section{Kaanta}

Deva Raja Radha. Shabdakalpadruma. Third ed. Varanasi (India): Chowkhamba Sanskrit Series Office; 1967. p.882.

3. Deussen, P. The philosophy of Upanishads, translated in English by A.S.Geden, T\&T Clark, Edinabargha;1906

4. Trikamjin Yadavji. Charaka Samhita with Chakrapanidatta Ayurvedadipika commentary. Reprint ed. Varanasi (India): Chaukhamba Surbharati Prakashana ;2011. p.74.

5. Benjamin James Sadock, Virginia Alcott Sadock, Kaplan \& Sadock's; Concise text book of clinical psychiatry; 3rd Edition. Chapter no 20, New Delhi, Wolters Kluwer (India)Pvt Ltd;2007., p no.349.

6. Benjamin James Sadock, Virginia Alcott Sadock, Kaplan \& Sadock's; Comprehensive Text Book of Psychiatry; 3 rd Edition, Chapter no 20, New DelhiWolters Kluwer (India)Pvt Ltd;2007., p no. 2150. 
7. Shastri Kaviraj Ambikadatta. Sushruta Samhita with Ayurveda Tatva Sandipika vol-2. Reprint ed. Varanasi (India): Chaukhambha Sanskrit Samsthana publishers; 2010. p.515.

8. Yadavji Trikamaji Acharya editor, Charaka Samhita, Sutrastana, Chapter no 21, shloka no 35, Varanasi: Chaukambha Sanskrit Prakashan; 2014. p no.119.

9. Brahmananda Tripati commentator. Sharangadhara Samhita; Poorvakhanda 8, shloka no 67, Varanasi: Chaukhambha Surbharati Prakashan; 2007, p.87.

10. Jadavji Trikamji Acharya \& Narayanaram Acharya editor,Sushruta Samhita; Shareerastana, Chapter no 4, Shloka no.34, Varanasi; Chaukambha Sanskrit Sansthan, 2013, p no.358.

11. Shiva Prasad Sharma editor, Ashtanga Sangraha, Su- trastana, Chapter 9, Shloka no.56 Varanasi; Chaukhambha Sanskrit series 2012, p no. 183.

12. Brahmananda Tripati commentator. Sharangadhara Samhita; Poorvakhanda 8, shloka no 67, Varanasi: Chaukhambha Surbharati Prakashan; 2007, p.87.

13. Karnataka Vimala. Patanjali Yoga Sutravritti. Reprint ed. Varanasi (India): Chaukhamba Sanskrit Series Office;1996. p.33.

14. Yadavji Trikamaji Acharya editor, Charaka Samhita, Sutrastana, Chapter no
21, shloka no 58, Varanasi: Chaukambha Sanskrit Prakashan; 2014, p no. 119

15. Jadavji Trikamji Acharya \& Narayanaram Acharya editor,Sushruta Samhita; Shareerastana, Chapter no 4, Shloka no.33, Varanasi: Chaukambha Sanskrit Sansthan,2013, p no. 358.

16. Shiva prasad sharma editor, Astanga sangraha, Su- trastana Chapter 9, shloka no 52 Varanasi: Chauk- hambha sanskrit series; 2012, no.93.http://www.nhlbi.nih.gov/health/he alth top- ics/sdd/how much .html [as accessed on 29 august 2013].

17. Trikamjin Yadavji. Charaka Samhita with Chakrapanidatta Ayurvedadipika commentary. Reprint ed. Varanasi (India): Chaukhamba Surbharati Prakashana ;2011. p.119.

18. Assefas. Z, Diaz-Abad, M. Wickevire E.M et al. The functions of sleep Neuroscience. 2015: vol 12, Issue 3:155$171[$ Pubmed].

19.Karnataka Vimala. Patanjali Yoga Sutravritti. Reprint ed. Varanasi (India): Chaukhamba Sanskrit Series Office;1996. p.41.

20. Trikamjin Yadavji. Charaka Samhita with Chakrapanidatta Ayurvedadipika commentary. Reprint ed. Varanasi (India): Chaukhamba Surbharati Prakashana;2011. p.118 
